\title{
Print Media and the History of Women's Sport in Africa: The Kenyan Case of Barriers to International Achievement
}

\author{
Michelle Sikes
}

\begin{abstract}
This article explores one source through which African women's sport history can be drawn and interpreted: the sport sections of African newspapers. In the case of Kenya, the major dailies, Daily Nation and The East African Standard, are repositories of information pertaining to the challenges that confronted female athletes. Taking into account the history and development of these media, the article addresses the question of why did Kenyan women lag behind their male counterparts in entering the sport at an international level? Focusing on the early post-colonial period, it is argued that institutional barriers abroad as well as economic and cultural factors at home disproportionately disadvantaged female runners in their career progression. These conclusions would be difficult to substantiate without investigating the Kenyan press, a valuable source for anyone seeking to access information about the lives of the women who have contributed to Africa's sport history.
\end{abstract}

Résumé: Cet article examine les pages "sports" des journaux africains, une source qui permet l'étude et l'interprétation de l'histoire du sport pratiqué par les femmes africaines. Dans le cas kenyan, les défis auxquels devaient faire face les femmes athlètes étaient publiés dans les grands quotidiens Daily Nation et The East African Standard. En prenant en compte l'histoire et le développement de ces media, cet article adresse les raisons expliquant le retard des femmes athlètes pour rentrer dans l'arène internationale par rapport à leurs homologues

History in Africa, Volume 43 (2016), pp. 323-345

Michelle Sikes is a Lecturer in Sociology at Stellenbosch University. Her research and published work have focused on the social and economic history of women's sport in Kenya. E-mail: MMSikes@gmail.com 
masculins. Cet article suggère que les barrières institutionnelles à l'étranger mais aussi les facteurs culturels et économiques au Kenya désavantageaient de manière disproportionnée les coureuses féminines dans leur carrière. Il serait difficile d'aboutir à ces conclusions sans une étude de la presse kenyane, une source précieuse pour quiconque veut étudier les vies des femmes qui ont contribué à l'histoire du sport en Afrique.

\section{Introduction ${ }^{1}$}

Female Kenyan runners first competed at the Olympic Games in 1968. According to the East African Standard, "the selectors of the Kenya Amateur Athletics Association have taken a bold step by including these three [women] in the team to the $19^{\text {th }}$ Olympic Games due to open in Mexico City." 2 Lydia Stephens, Tecla Chemabwai, and Elizabeth Chesire were the three female runners flown from Kenya to Mexico, part of an eighteen-person athletics team captained by Kipchoge Keino. ${ }^{3}$ Stephens raced in both the 100 and 200 meters, Chemabwai competed in the 400 meters, and Chesire the 800 meters.

Sport, particularly running, has been a defining component of Kenya's history. ${ }^{4}$ Yet despite the participation and accomplishment by female Kenyan athletes in every Olympics since $1968,{ }^{5}$ studies of Kenyan sport by sociologists, geographers, and anthropologists have focused on men. ${ }^{6}$ Women's sport remains a lacuna in the historiography of East African athletics that has only recently attracted significant attention

1 The research and writing of this paper have been supported by the Rhodes Trust, the Beit Fund, and Lincoln College (Oxford). I am grateful to David Anderson, Matt Carotenuto, Nic Cheeseman, Tom Cunningham, Jan-Georg Deutsch, Anne Heffernan, Deborah Oxley, Lance van Sittert, Arthi Vellore, and the anonymous referees of this journal for their helpful comments and suggestions.

2 Hezekiah Wepukhulu, "Trio Make History," East African Standard (3 August 1968), 31.

3 Standard Staff Reporter, "Kenya's final team for Mexico City," East African Standard (6 September 1968), 24.

4 The term "athletics" will also be used interchangeably with "running" to denote the broad range of activities that include competitive exertions in trackand-field, cross-country and marathons.

5 This excludes the 1976 and 1980 Olympic Games, which Kenya boycotted.

6 See, for instance: John Manners, "Kenya's Running Tribe," The Sport's Historian 17-2 (1997), 14-27; George Godia, "Sport in Kenya," in: Eric Wagner (ed.), Sport in Asia and Africa (New York: Greenwood Press, 1989), 260-281; Peter Mahlmann, "The Role of Sport in the Process of Modernisation: The Kenya Case," Journal of Eastern Africa Research and Development 23 (1993), 160-175; Wycliffe Njororai, "Colonial Legacy, Minorities and Association Football in Kenya," Soccer E Society 10-6 (2009), 866-882; Wycliffe Njororai, "Global Inequality and Athlete Labour Migration From Kenya," Leisure/Loisir 34-4 (2010), 443-461. For a review of recent literature on sport in Africa, see: Marc Fletcher and Lizelle Bisschoff, "African Sport in the Global Arena: Contemporary Approaches and Analyses,” Critical African Studies 6-2/3 (2014), 123-133. 
from Africanist historians. ${ }^{7}$ The setbacks and successes of East Africa's sportswomen have been sporadically noted and the concept of gender rarely employed. ${ }^{8}$

This is evident in both monographs and edited collections. ${ }^{9}$ The seminal text in the field, Kenyan Running: Movement Culture, Geography and Global Change, lacks indexed entries for women or gender or female athletes. Writing about the colonial period, co-authors John Bale and Joe Sang claim that "women athletes have not been mentioned simply because they were not significantly involved." ${ }^{0}$ It was the case that male runners were the predominant actors and focus of attention from officials and in the media at the time. Yet when the absence of women goes unquestioned, masculinity is often also left unexplored. This situation also raises questions of why women were excluded from sport initially, and persistently, and how some women overcame this. By the time of Kenyan Running's publication in 1996, World Championship medals had been won by Susan Sirma in the 3,000 meters, Sally Barsosio in the 10,000 meters, and Tegla Loroupe in the 10,000 meters. Their emergence receives no analysis by

7 For a discussion of why Africanists should study sports, see: Bea Vidacs, "Through the Prism of Sports: Why Should Africanists Study Sports," Afrika Spectrum 41-3 (2006), 331-349.

8 Only two book-length edited volumes have been published on this topic: Michelle Sikes and John Bale (eds.), Women's Sport in Africa (Abingdon: Routledge, 2014); Jimoh Shehu (ed.), Gender, Sport and Development in Africa: Cross-Cultural Perspectives on Patterns of Representations and Margalization (Dakar: CODESRIA, 2010). Historical studies of women's sport have been most forthcoming for the South Africa context though largely as articles and chapters of edited collections. See: Denise Jones, "Women and Sport in South Africa: Shaped by History and Shaping Sporting History," in: Ilse Hartmann-Tews and Gertrud Pfister (eds.), Sport and Women: Social Issues in International Perspective (London: Routledge, 2003), 130-144; Prishani Naidoo and Zanele Muholi, "Women's Bodies and the World of Football in South Africa," in: Ashwin Desai (ed.), The Race to Transform: Sport in Post-Apartheid South Africa (Cape Town: HSRC Press, 2010), 105-145; Martha Saavedra, "Football Feminine - Development of the African Game: Senegal, Nigeria and South Africa," Soccer Eं Society 4-2 (2003), 225-253.

9 Women and discussion of gender are also neglected in popular writing on Kenyan running. Jurz Wirz prefaces Run to Win with an explicit apology to "female readers" for the extent to which men are prominent in his book: Jurz Wirz, Run to Win:Training Secrets of the Kenyan Runners (Oxford: Meyer \& Meyer Verlag, 2006), 13. See also: Dave Prokop (ed.), The African Running Revolution (Mountain View CA: World Publications, 1975); Adharanand Finn, Running with the Kenyans: Discovering the Secrets of the Fastest People on Earth (London: Ballantine Books, 2012); Toby Tanser, Train Hard, Win Easy: The Kenyan Way (Mountain View CA: World Publications, 1997). Some discussion of female runners can be found in Toby Tanser, More Fire: How to Run the Kenyan Way (Pennsylvania: Westholme Publishing, 2008).

10 John Bale and Joe Sang, Kenyan Running: Movement Culture, Geography and Global Change (London: Routledge, 1996), 96. 
Bale and Sang or other authors, however. ${ }^{11}$ Rather than investigate why, as the authors put it, it was "only" in 1994 that Helen Chepng'eno became the first Kenyan woman to win the world women's senior cross-country, the progress of female athletes is juxtaposed against "the fact that the overwhelming majority of Kenya's great athletes have been men" and then given no further attention. A more accurate and detailed picture of women's sport history would inform our understanding of the trajectory of sport development as well as help to unlock answers to questions of the mechanisms that were responsible for its progress or impedance.

In the second major book on this topic, East African Running: Towards a Cross-Disciplinary Perspective, the editors acknowledge that "there is little [in this book] that deals with issues of gender." 12 John Bale wrote the single historical chapter opening the collection, which was published eleven years after his Kenyan Running. ${ }^{13}$ Detailing the rise of athletics in Kenya, the chapter explored the antecedents to Kenyan runners' success, culminating with the 1968 Mexico City Olympics. Although Kenyan women represented their country for the first time in those Games, that hallmark event earned no mention. Also left out of this narrative were the Kenyan women who competed domestically during the years prior to their 1968 Olympic debut. Unacknowledged were the facts that the inaugural Colony Women's Championships was organized in $1959^{14}$ and that women were competing in Provincial Championships from 1957,15 and in District and schools championships from the early 1950 s. ${ }^{16}$ As has been the case for the history of men's running, these records should be sought out and made perceptible, in conjunction with other sources, to shape what we think about Kenya's past.

Since the 1970s Africanist feminist writers have argued that such partial accounts are inadequate. These scholars have integrated the achievements and challenges of pioneering African women into a range of historical fields of inquiry but here too women's sport has been overlooked.

11 Mark Butler (ed.), IAAF Statistics Handbook (London: IAAF Media \& Public Relations Department, 2009).

12 Yannis Pitsiladis, John Bale, Craig Sharp, Tim Noakes and Norman Myers (eds.), East African Running: Toward a Cross-Disciplinary Perspective (London: Routledge, 2007), 1-8, 7.

13 John Bale, "Kenyan Running Before the 1968 Mexico Olympics," in: Yannis Pitsiladis, John Bale, Craig Sharp, Tim Noakes and Norman Myers (eds.), East African Running: Toward a Cross-Disciplinary Perspective (London: Routledge, 2007), 11-23.

14 Rift Valley Province Archive, PC/NKU/3/21/8, Athletics Sports Reports, 1957-1961, "Colony Women Championships, and Decathlon, 23 November 1959."

15 Rift Valley Province Archive, DC/KSM/1/1/227, "Nyanza Intermediate Schools Inter-district Athletic Meeting 1957 Results."

16 Rift Valley Province Archive, DC/KSM/1/1/228, "Provincial Sports Meeting for Training Centres and Secondary Schools Held at Siriba, 11 July 1953.” 
Overviews of the history of African women reveal that the continent's fastest sportswomen have failed to capture the attention of its historians. ${ }^{17}$ Chepyator-Thomson's African Women and Globalization stands out for allocating one chapter of thirteen to women in sport. ${ }^{18}$ As an anthology not thematically related to athletics, the volume is exceptional for containing a single piece on female runners. The opportunity to use sport as a means to explore changes in economic and social relations within the household, and between the household and community, has been generally missed.

Paucity of source material contributes to the neglect of sportswomen in these historiographies. In a search limited to a survey of documentation housed in the Kenyan National Archives, one finds tends to find summations about the development of sport that pay little attention to women. The challenge for the historian interested in women's sport is to piece together bits of evidence drawn from other sources beyond official reports and correspondence. This article focuses on one source through which the history of African women's sport can be drawn, arranged and given meaning: the sport sections of national newspapers. ${ }^{19}$ The major English-language dailies, Daily Nation and The East African Standard, emerge as important and accessible repositories of information about the challenges that confronted female runners in Kenya in the early postcolonial period.

Newspapers in general provide abundant categorization of the events, concerns and debates of the past. They offer access to detailed descriptions of social stories and conflicts that are constantly unfolding. Historians often target newspapers as a source, not only about concrete events and dates but also about changing attitudes, ideas and identities. Although accounts of sport victories and defeats in newspapers has been as ubiquitous in the East African press as it has been in Europe and North America, and running has long been one of the top items within Kenyan newspapers'

17 Catherine Coquery-Vidrovitch, African Women: A Modern History (Boulder CO: Westview Press, 1997); Iris Berger and Frances White (eds.), Women in Sub-Saharan Africa: Restoring Women to History (Bloomington IN: Indiana University Press, 1999); Nancy Hunt, "Placing African Women's History and Locating Gender," Social History 14-3 (1989), 359-379; Andrea Cornwall, "Introduction: Perspectives on Gender in Africa," in: Andrea Cornwall (ed.), Readings in Gender in Africa (Oxford: James Currey, 2005), 1-19; Ayesha Imam, Amina Mama and Fatou Sow (eds.), Engendering African Social Sciences (Dakar: CODESRIA, 1997).

18 Jepkorir Rose Chepyator-Thomson, "African Women Run for Change: Challenges and Achievements in Sports," in: Jepkorir Rose Chepyator-Thomson (ed.), African Women and Globalization: Dawn of the 21 ${ }^{\text {st }}$ Century (Trenton NJ: Africa World Press, 2005), 239-258.

19 This discussion is based upon work undertaken for my $\mathrm{PhD}$ dissertation; in the course of research I consulted more than two thousand newspaper articles from Daily Nation and The East African Standard. 
sport pages, historians have not fully taken advantage of this resource. This article will demonstrate the ways in which the sports section of the Englishlanguage Kenyan press offers a valuable source for Africanists interested in gender history.

Specifically, it does this through addressing the question of why did Kenyan women lag behind their male counterparts in entering the sport at an international level? Focusing on the early post-colonial period, it is argued that institutional barriers in Kenya, in terms of a lack of opportunities to qualify for international races, and in the United States, through delayed implementation of Title IX legislation ${ }^{20}$ that would eventually fund Kenyan women's training, as well as cultural factors disproportionately disadvantaged female Kenyan runners in their career progression. ${ }^{21}$ These conclusions would be difficult to substantiate without the sports page in the Kenyan press, highlighting its value as a historical source that offers great scope for further investigation by Africanist historians.

\section{The Kenyan Press: The East African Standard and Daily Nation}

The Daily Nation is currently Kenya's most popular major daily. ${ }^{22}$ Published by Nation Media Group (NMG) and owned by the Aga Khan, it first appeared in Kenya in $1959 .{ }^{23}$ At the time, the paper presented a challenge to The East African Standard, and initially set itself apart by adopting a policy of Africanization. ${ }^{24}$ The East African Standard is Kenya's oldest paper, reporting "from pre-independence, through Uhuru, to post-independence." 25

Both papers have endured, providing a continuous narrative of events that enhances their utility as a source for historians. In the case of The East African Standard, Kenyan history can be traced through its pages over the course of more than a century. Its past publications have been archived in its Nairobi headquarters, which can be combined with the searchable

20 "Title IX" is a piece of legislation enacted in the United States as part of the Education Amendments of 1972. The law prohibits discrimination on the basis of sex in any federally funded education program or activity. It took three years (1972-1975) to translate Title IX into specific regulations and further resistance to the application of the law to athletic programs delayed its widespread implementation until the early 1980s.

21 Although the racing opportunities in Europe were also important, in the pre-professional era, the United States was pivotal in the Kenyan context because of its university sports programs with full scholarships available to student-athletes, discussed at greater length below.

22 Both major dailies have changed names over the years. For consistency, Daily Nation and The East African Standard will be used throughout this essay.

23 Gunilla Faringer, Press Freedom in Africa (New York: Praeger, 1991), 36.

24 Faringer, Press Freedom in Africa, 36.

25 Brian Tetley, "Moving into the $21^{\text {st }}$ Century," East African Standard (20 February 1995), 6. 
online database of articles allafrica.com and newspaper holdings in Rhodes House Library in Oxford, newspaper collections in the British Library, and the US Library of Congress, to build a collection from the early years of the twentieth century.

This has implications for the historical study of sport in particular. Okigbo and colleagues conducted a comparative quantitative content analysis of the most widely read newspapers in Nigeria and Kenya, including The East African Standard and Daily Nation. ${ }^{26}$ Their sampling looked at the period from June 1994 to June 1995 and confirmed that the Kenyan media affords sport significant space. Sport during that period occupied an average of 18.3 percent of the total news coverage, behind only reports on government activities and the economy, which occupied 25.1 percent and 19.3 percent respectively. ${ }^{27}$ The researchers also found that articles overtly concerning gender, which they defined as "stories depicting stereotypes of men and women's behavior and activities, female circumcision and those on meetings or conferences focusing on gender," received very little coverage - only 1.6 percent of all published stories. ${ }^{28}$ It is therefore all the more important to use sports coverage as an alternative way to study gender.

Repressive state influence on the press has given rise to investigations into the constraints of the Kenyan print media as source material. ${ }^{29}$ However, political curbs under both colonial and post-colonial governments targeted certain areas, namely headline news, editorials, economic features and opinion columns. Ogola highlighted this in his analysis of a humor column, Whispers, that appeared within both The East African Standardand Daily Nation. ${ }^{30}$ "It is in these marginal sites within the newspaper that one sees the making of the 'social space' in the Kenyan newspapers." 31 Sub-genres that

26 Charles Okigbo, Festus Eribo, Mary Kizito and Christine Kyayonka, "Beyond Cameroon: Model Content Analysis from East and West Africa," in: Festus Eribo and Enoh Tanjong (eds.), Journalism and Mass Communication in Africa: Cameroon (Lanham MD/Oxford: Lexington Books, 2002), 133-150.

27 Okigbo et al., "Beyond Cameroon," 141-142.

28 Okigbo et al., "Beyond Cameroon," 138.

29 Bodil Folke Frederiksen, "Print, Newspapers and Audiences in Colonial Kenya: African and Indian Improvement, Protest and Connections," Africa 81-1 (2011), 155-172; Fay Gadsden, "The African Press in Kenya, 1945-1952," Journal of African History 21-4 (1980), 515-535; Faringer, Press Freedom in Africa; George Ogola, "If You Rattle a Snake, Prepare to be Bitten: Popular Culture, Politics and the Kenyan Media," in: Herman Wasserman (ed.), Popular Media, Democracy and Development in Africa (Abingdon: Routledge, 2011), 123-136; George Ogola, "The Idiom of Age in a Popular Kenyan Newspaper Serial," Africa 76-4 (2006), 569-589.

30 George Ogola, "Confronting and Performing Power: Memory, Popular Imagination and a 'Popular' Kenyan Newspaper Serial," African Studies 64-1 (2005), 73-85.

31 Ogola, "Confronting and Performing," 74. 
were deemed politically inconsequential, including sport, were largely unaffected by such direct censorship. Sport journalists could write unfettered by external dilution or restriction, leaving sport coverage an uncensored window through which to discern the prevailing social values and identities of the time.

Although free from direct censorship, Kenyan sport journalists writing for the major papers were nonetheless systematically silent in one regard: acknowledgement of ethnicity. They largely refrained from reporting on athletics in ethnic terms or from drawing attention to the particular dominance of runners from one region over another. This is curious because, as Anderson and Cheeseman have observed, the emphasis placed on Kenyan (and African) ethnicity in other contexts, including academic writing, often tends to obscure the significance of other salient identities, including gender. ${ }^{32}$

The omission is also striking given the prominence and disproportionate success of Kalenjin runners among Kenya's top athletes. Accounting for 11 percent of the total population, the Kalenjin have won about 75 percent of the country's medals at major international athletics competitions and can claim half of the top-ten times in distance races contested at the Olympics. ${ }^{33}$ Between 1963 and 1975, all of Kenya's forty-five Olympic and Commonwealth Games medals were won by either Kalenjin or Kisii runners. ${ }^{34}$ Looking at a longer period from independence until the mid-1990s, male Kalenjin distance runners in track distances from 800 meters to 10,000 meters in the Olympic Games dramatically outpreformed competitors from other countries and other parts of Kenya, as shown in Figure 1.

A study published in 2014 aimed to investigate the ethnicity of Kenya's most successful international runners, tracking this over the period of their

32 David Anderson and Nic Cheeseman, "An Introduction to African Politics," in: David Anderson, Nic Cheeseman and Andrea Scheibler (eds.), Routledge Handbook of African Politics (Abingdon: Routledge, 2013), 1-8. For a monograph on Kalenjin ethnicity, see: Gabrielle Lynch, I Say to You: Ethnic Politics and the Kalenjin in Kenya (Chicago: University of Chicago Press, 2011); for a detailed history of the Tugen, a sub-group of the Kalenjin, see: David Anderson, Eroding the Commons: The Political Ecology in Baringo, Kenya 1890-1963 (Oxford: James Currey, 2002).

33 John Manners, "Raiders from the Rift Valley: Cattle Raiding and Distance Running in East Africa," in: Yannis Pitsiladis, John Bale, Craig Sharp, Tim Noakes and Norman Myers (eds.), East African Running: Toward a Cross-Disciplinary Perspective (London: Routledge, 2007), 40-50; John Manners, "Kenya’s Running Tribe." See also: Randall Mayes, The Cybernetics of Kenyan Running (Durham NC: Carolina Academic Press, 2005).

34 John Manners, "In Search of an Explanation,” in: Dave Prokop (ed.), The African Running Revolution (Mountain View CA: World Publications, 1975), 26-40. 
Figure 1. Medals, Men's Track Events 800 Meters to 10,000 Meters - Olympic Games, 1964 to 1996. Source: J. Manners, "Kenya's Running Tribe," 16. (Note this excludes the Games that Kenya boycotted in 1976 and 1980.)

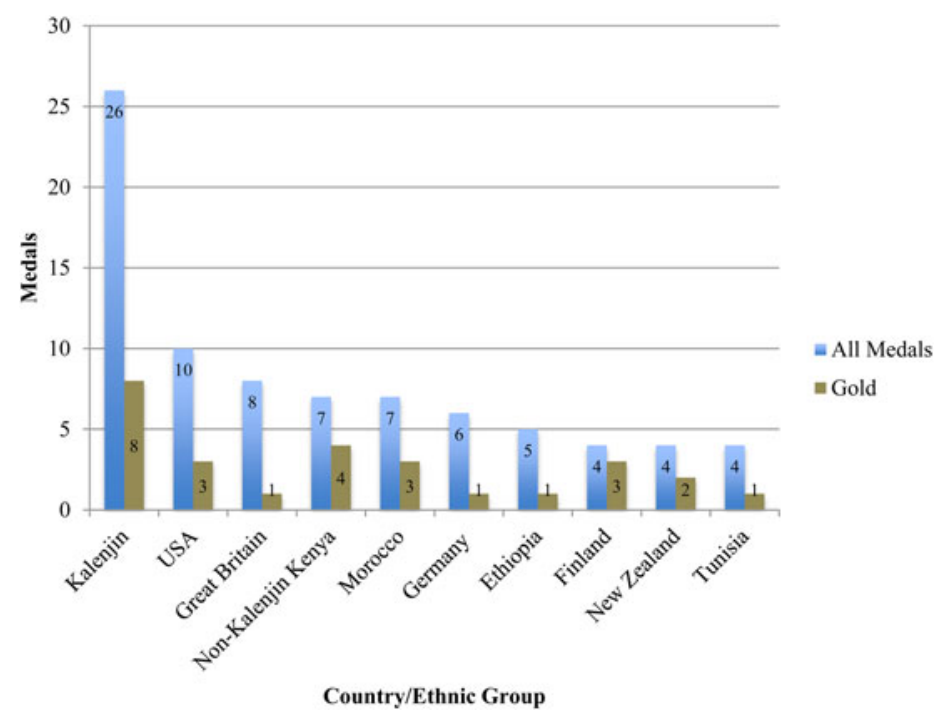

international emergence and current dominance. ${ }^{35}$ Considering male track distance events from the 800 meters upwards from all the major global athletics championships from 1964 to 2013, and the annual top-25 world marathon performances since 1990, the authors found that the dominance of African distance runners is primarily a Kenyan phenomenon, driven by the Kalenjin, and in particular, the Nandi sub-ethnic group.

Yet journalists refrained from drawing attention to this divergence, though they did write fairly consistently about female athletes, even if it was to highlight their absence. The first African sports editor of the Nation Media Group, Philip Ndoo, was particularly vocal in this regard. ${ }^{36}$

35 Ross Tucker, Vincent Onywera and Jordan Santos-Concejero, "Analysis of the Kenyan Distance Running Phenomenon," International Journal of Sports Physiology Performance 10-3 (2015), 285-291.

36 Hezekiah Wepukhulu, "Philip Ndoo's Untold Story of the Olympic Movement in Kenya," The East African (14-20 February 2005), 8. Born in 1946, Ndoo represented Kenya in the steeplechase at the 1970 Commonwealth Games. He received a track scholarship in 1972 from Eastern New Mexico University, where he obtained degrees in journalism and economics. While working as a journalist, Ndoo coached Kenyan teams at the 1977 All-African Games held in Algeria and at the Commonwealth Games in Canada the following year. In 1984, he travelled as an executive officer to the Olympics in Los Angeles and he was a member of the organizing committee of the 1987 All-African Games held in Nairobi. Ndoo passed away at 58 , in 2005 , after battling with throat cancer. 
In an 1986 article titled "Women: Plenty but Usually Wasted Talent," he declared: "Kenya has as many talented women in athletics as men, but for various reasons, Kenyan women have lagged far behind in performance, especially on the international scene." 37 Warming to the theme in another piece published that year, he lamented: "Kenya is littered with numerous women athletes who have shown great potential at the tender ages, only to fade away when they should be maturing." 38 His expressions of disapproval were sustained over time; as early as 1970, he was wondering why the "home of middle distance runners like Kip Keino" did not have women running to the same standard. ${ }^{39}$ But Ndoo was not alone in his concern. As Peter Moll put it bluntly in a 1972 report: "The paucity of women's athletic talent in Kenya will be as revealing as a miniskirt at this weekend's national championships in Mombasa." 40 For another Kenyan journalist in 1992, "Kenyan women have lived under the shadows of their male counterparts at the Olympic stages for many years." 41 Questions of why Kenya's sportswomen were not "keeping pace" with the men were invoked far more often than queries of why Kalenjin runners were more successful than athletes from other ethnic groups.

Bodil Folke Frederiksen explored a similar puzzle in her work on urban culture in Kenyan popular writing. ${ }^{42}$ In that genre, questions of masculinity and femininity were prevalent while ethnic relations and identities were not mentioned. She observed that gender could be "debated, flaunted and engaged with (...) whereas African ethnicity leads a secret and furtive life." 43 For Frederiksen, explanation could be found in how ethnicity had been highly politicized in ways that gender had not. Gender was far less of a basis for political mobilization, which freed it for public debate, and this can be discerned not only in the writings of popular culture but also in those about sport. Interpretation of sport and sport identities does not simply flow from journalists to readership apolitically, rather, it is a cultural product subject to negotiation and reconsideration

37 Philip Ndoo, "Women: Plenty but Usually Wasted Talent," Daily Nation (16 August 1986), 22.

38 Philip Ndoo, "Onyambu Survives the Fading Bug," Daily Nation (16 September 1986), 29.

39 Philip Ndoo, "Medals for these Kenya Schoolboys," Sunday Nation (9 August 1970), 37.

40 Peter Moll, "Adala - Running Back to Happiness," Daily Nation (22 June 1972), 23.

41 Gishinga Njoroge, "Women's Best Chance Since Mexican Debut," Daily Nation (4 March 1992), 25.

42 Bodil Folke Frederiksen, "Gender, Ethnicity and Popular Culture in Kenya," The European Journal of Development Research 6-2 (1994), 52-62.

43 Frederiksen, "Gender," 58. 
and situated within a wider field of social and political constraints as Karin Barber has addressed. ${ }^{44}$

The next section addresses the question about women raised within the Kenyan press itself - namely, what constrained Kenyan women in running, relative to their male counterparts? Answers are found in the evidence available within the papers themselves, demonstrating the types of historical investigations that are possible through studying the sports sections of the major English-language print media.

\section{Pregnancy and other Roadblocks to Success in Running}

In the early 1970s, Sabina Chebichi's name stood out from among the bevy of Kenyan schoolgirl runners. In 1973, at a major Brooke Bondsponsored meet in Kericho, Chebichi won her first race barefoot and wearing her school uniform. Thereafter dubbed the "Petticoat Princess" for the skirt in which she raced, the 14-year-old from Mlimani Primary School near Kitali was awarded a pair of spikes, her first, as well as shorts and a vest. ${ }^{45}$ The second oldest of nine children, Sabina's circumstances were similar to those of many schoolchildren growing up in the highlands of the Rift Valley at that time. Her homestead was some 25 miles from her primary school, and during the school holidays, she "help[ed] to weed crops at her father's farm and do the usual household chores." 46

In her running achievements, however, Sabina was anything but ordinary. As the 1973 season progressed, it was not just her apparel that captured media attention; her wins were record-breaking. That year, she recorded some of the fastest times in Africa for 800 meters and 1,500 meters. She also won the bronze medal in the 800 meters at the 1974 Commonwealth Games in Christchurch, New Zealand, becoming the first female from Kenya to medal at the Commonwealth Games.

Such performances came with an expectation of future distinction in international and Olympic competition. One report suggested: "[I]f Sabina can continue training hard, there is no reason why she should not win a medal in the Olympic Games and become the first-ever woman from Africa to do so."47 Described as "precocious" and "Kenya's latest track wonder," she routinely defeated more experienced runners. ${ }^{48}$

44 Karin Barber, "Popular Arts in Africa," African Studies Review 30-3 (1987), 1-78; Karin Barber, "Preliminary Notes on Audiences in Africa," Africa 67-3 (1997), 347-362.

45 Nation Sports Reporter, "Guinness Award," Daily Nation (10 July 1973), 27.

46 Nation Sports Reporter, "Kenya's Latest Track Wonder...Sabina,” Daily Nation (8 February 1974), 30.

47 Nation Sports Reporter, "Kenya's Latest Track Wonder...Sabina," Daily Nation (8 February 1974), 30.

48 Nation Sports Reporter, "Kenya's Latest Track Wonder...Sabina," Daily Nation (8 February 1974), 30. 
Yet not long after bursting onto the international running scene, Sabina became pregnant. These lofty ambitions ultimately went unrealized. As one sports journalist wrote about Chebichi in Daily Nation:

This teenager ran a world-class time in Christchurch in 1974. She could have broken the world record in both the $800 \mathrm{~m}$ and $1500 \mathrm{~m}$ events the following year. But where was she? She was pregnant. Another unwed mother. It is possible to have children at the age of 40 but one cannot set world records at this age. These girls need advice. ${ }^{49}$

Other female athletes who emerged successfully as international runners agreed that early pregnancy curtailed talented peers' progression in sport. In an interview with Daily Nation, 1984 Olympian Ruth Waithera put forward that "girls who start rising in athletics and are then interrupted by pregnancy never seem to recover." 50

Paying attention to the words of "ordinary" runners presented in the press also offers a glimpse into the social dynamics that surrounded women's sport in Kenya. For instance, evidence recovered from the sport section illustrated that a relationship with an unsupportive partner proved inimical to a successful running career. The Standard reported that:

Women athletes interviewed here state that demoralization in their performance as they approach maturity comes from their boyfriends. Some say that [being with] a man who has little or no interest in the sport is the biggest hardship in a track career. ${ }^{51}$

Female athletes considered their partner's disapproval as the most significant factor hindering their development in sport. In another article, The East African Standard noted that "some athletes said boyfriends ruin a career" and quoted a sprinter who said:

When you love a man with no interest to the sport, you end up declining. The man will tell you to choose between him and the sports. Of course I will choose him. ${ }^{52}$

49 Pekka Rinne, "The Ills Plaguing Kenya Athletics," Daily Nation (7 April 1976), 20.

50 Gishinga Njoroge, "A True Heroine on Track and Off," Daily Nation (21 March 1992), 15.

51 Charles Kariuki, "Veteran American Coach Tells it All," East African Standard (22 April 1989), 12.

52 Charles Kariuki, "Women Athletes," East African Standard (29 April 1989), 13. 
There were considerable social pressures to "choose him" over athletics and this admission reveals continuities of gender that can be traced back to the pre-colonial and colonial past. ${ }^{53}$ If women were to continue to participate in sport as wives and mothers, they would need to train, travel and race without their children, and would therefore need to depend on the support of family and partner. Yet as of the late 1980s, many men were unwilling to support this arrangement and women often saw no alternative but to acquiesce and give up running. Articles from the sports section that quote female athletes give insight into the social fabric of the time, revealing the feelings, reactions, and perceptions of the athletes themselves about gender roles and relations.

Further, hardships particular to Kenyan athletics, from the absence of tracks with a consistently reliable surface, to long stretches of time without officially sponsored meets, adversely affected all runners training in Kenya. But as a group, women were more negatively impacted than men. Selection for international races was entirely dependent on a runner having first achieved the necessary qualification standard in official competition, and top Kenyan men could access many more opportunities to race abroad.

Particularly in the 1970s and early 1980s, before the era of professional sport, athletics scholarship from universities in the United States played a major role in male Kenyan runners' development. For athletes of any nationality, a sport scholarship from an American university was a remarkable opportunity. In exchange for four years of competitive athletics while maintaining grades above a certain threshold, the student-athlete received equipment, medical care, coaching, and ample competitive opportunities as well as a free college education. Prior to the 1970s, non-Americans, however, had been subject to an "alien student rule," which caused them to lose one year of NCAA eligibility for every year past the age of twenty (later change to nineteen) in which they participated in organized competition in their countries. The logic being that foreigners could be recruited out of high school and enrolled for four years but "if you waited and tried to pluck off some Olympic gold medal winner from Kenya, then you would have him for considerably less time." 54 The rule curtailed the involvement of foreigners who were unlikely at the age of nineteen to enter the world of intercollegiate athletics in the United States. ${ }^{55}$

On 10 December 1973, a federal court suspended this rule on grounds that it did not comply with the $14^{\text {th }}$ amendment's provision of equal

53 For further discussion of these themes, see: Michelle Sikes, "Choosing to Run: A History of Gender and Athletics in Kenya," PhD dissertation, University of Oxford (Oxford, 2014). See also: Michelle Sikes and Grant Jarvie, "Women's Running as Freedom: Development and Choices," Sport in Society 17-4 (2012), 507-522.

54 John Conrad, "Coaches Bemoan Foreign Flood," Eugene Register-Guard (12 June 1974), 9.

55 John Bale, The Brawn Drain (Urbana: University of Illinois Press, 1991), 47. 
protection under law, effectively removing all restraints on recruiting older foreign track runners. ${ }^{56}$ The group that would benefit significantly from the change were men; Kenyan women had to wait ten more years with their American counterparts for the implementation of gender equality legislation, around which time the rules were changed again to restrict foreign movement to NCAA colleges.

The decision to drop the "alien student rule" immediately had an impact on NCAA programs, particularly in athletics. In the first year after it was passed, twelve international-caliber Kenyan men arrived in the USA on track scholarships. For three successive years (1975 to 1977) at the NCAA Men's Outdoor Track Championships, foreign athletes won eight of the fifteen individual titles, with Kenyans claiming victories each year in the 3,000 meter steeple-chase, the 5,000 meters and the 10,000 meters. In 1976, Kenyans also took the top two places at the NCAA Men's Cross Country Championship, with the title going to Henry Rono of Kenya, then a 25-year-old freshman at Washington State. Rono would become only the third person in history to win the NCAA Men's Cross Country Championship three times, doing so in 1976, 1977, and 1979.

The beginnings of what would become a "pipeline" of athletes between Kenya and the United States can also be traced to the early 1970s when two men, Ghanaian sprinter George Daniels and Kenyan triple jumper Patrick Onyango, were awarded athletic scholarships to major NCAA sports programs. ${ }^{57}$ American student-athletes Bill Toomey and Mark Winzenried had met them the previous year during a US Information Services tour of Africa. ${ }^{58}$ Toomey recruited Daniels for his alma mater Colorado and Winzenried, still a student, persuaded Onyango to join him at Wisconsin. A second pair that played a role were Kenyans Julius Sang and Robert Ouko, who arrived together at North Carolina Central University in 1971 to compete in the 400 meters and 800 meters, respectively. The two attracted so much attention for their outstanding performances at their first NCAA Championship, as well as for the medals they won subsequently at the 1972 Olympics, that American coaches were soon scrambling to establish "African connections" in the wake of the 1973 ruling.

The case of Washington State University illustrates how connections developed between American universities and secondary schools in the Rift Valley. Washington State's link was established when a Kenyan lecturer at the University of Puget Sound contacted then assistant track coach at

56 Neil Amdur, "Issue and Debate: Is College Recruiting of Foreigners Excessive?," The New York Times (15 March 1977), 46.

57 Though he did not receive an athletics scholarship, the first Kenyan athlete to compete for an American university was Steve Machokos at Cornell. See: Prokop, The African Running Revolution.

58 John Manners, “African Recruiting Boom,” in: Dave Prokop (ed.), The African Running Revolution (Mountain View CA: World Publications, 1975), 62-69. 
Washington State, John Chaplin, regarding a friend reputed to be an excellent distance runner. Although "skeptical," Chaplin recruited the runner and in 1974, John Kipkemoi Ng' eno arrived in the Pacific Northwest. As a Washington State student, Ng'eno became a multiple-time NCAA champion and one of the world's fastest 10,000-meter runners. By 1977, Kenyan competitors contributed 24 of the 25.5 points that gave Washington State its first national team title at the NCAA Indoor Track and Field Championship. 59

The coming together of American legal precedent, well-resourced American universities, and gifted Kenyan runners created the conditions for many of Kenya's best male runners to spend four years developing their running abilities in the United States. From 1971 to 1978, Kenyans made up 17.2 percent of non-American competitors at the NCAA Men's Championships, the most of any foreign nation during this period. ${ }^{60}$ As Figure 2 shows, for that period until 1985, Kenya outperformed all other nations in sending track-and-field athletes who qualified for and competed at the NCAA Championships.

Long-term Iten-based coach Brother Colm O’Connell commented that the lure of a scholarship to America was especially important for developing and preserving local interest in the sport during the period in which Kenya boycotted successive Olympics of 1976 and $1980 .{ }^{61}$ The movement of male runners between Kenya and America accelerated until the 1980s, when objections to the extent of overage recruiting led the NCAA to reinstate limitations of eligibility based on the ages of the athletes involved, tempered somewhat by making an allowance for the number of years spent in pre-collegiate competition. The rising professionalization of athletics and the resulting monetary rewards also reduced the allure of accepting a scholarship for running as an amateur athlete. The year 1982 was the peak of Kenyan runners' migration to American universities, with twenty-four of the fifty best male Kenyan 5,000 meters runners attached to colleges in the United States. 62

The dearth of women in this narrative highlights the extent to which the long delay in enforcing Title IX, legislation that mandated equal funding for men's and women's athletics at all federally funded American schools and universities, adversely affected the development of women's running in both America and Kenya, though it was not the only factor limiting women's involvement in sport at that time. Tecla Chemabwai, Rose Chepyator-Thomson, and Ruth Waithera were virtually the only Kenyan

59 John Manners, "Track is Main Attraction: Foreign College Athletics Becoming More Common,” The New York Times (16 March 1977), 7B.

60 Bale and Sang, Kenyan Running, 125.

61 Colm O’Connell (interview, Iten, 15 January 2010).

62 Bale and Sang, Kenyan Running, 125. 
Figure 2. National Origin of Superior Foreign, Male Track-and-Field Athletes at American Colleges, 1973-1985. Source: Bale and Sang, Kenyan Running, 125.

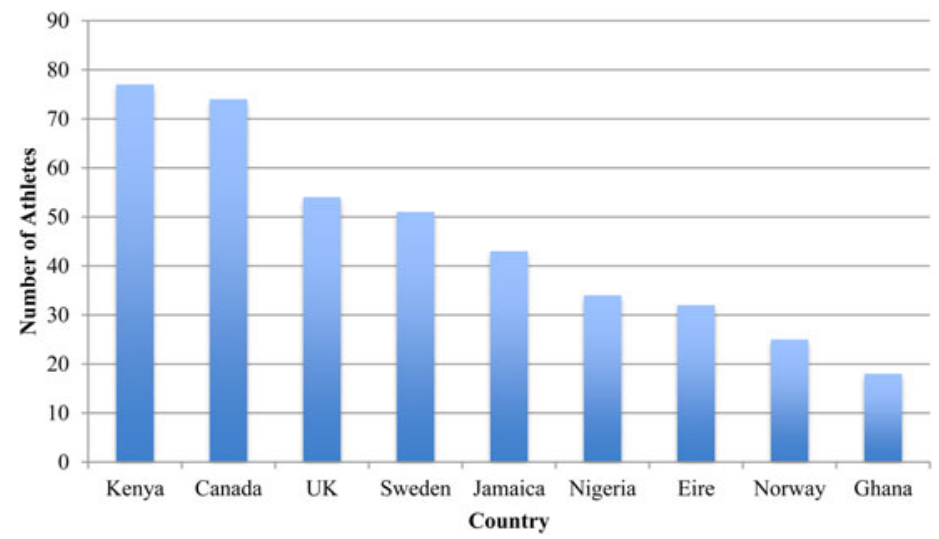

women to take advantage of the opportunities opening to women in the United States during this period. ${ }^{63}$ Chemabwai left for the United States in 1973, Chepyator-Thomson was next, enrolling to study Physical Education at the University of Wisconsin-Madison from 1979-1983, while Waithera attended the University of Arizona from 1981-1984. They also became Kenya's best international-caliber athletes throughout the seventies and early eighties.

Chemabwai was the first woman from Kenya to earn a scholarship. One year after accepting Chicago State University's offer to study and run, she became the first Kenyan woman to win a gold medal at a major Games. Chepyator-Thomson won All-American honors while studying at Wisconsin and for a time, held the African record in the 3,000 meters. Waithera became the first woman from Kenya to qualify for the finals in any event at the Olympics when she competed in the 400 meters at the 1984 Los Angeles Games during the summer after her graduation. These women contributed to the "pipeline" of talented runners from Kenya to American universities characteristic of the late 1970 s and 1980s. ${ }^{64}$ However, although this was the peak period of unfettered eligibility for foreigners, due to delays in implementing Title IX across most US universities, they were a rarity. On the US inter-collegiate circuit, female Kenyan runners were at least ten years behind male Kenyan runners.

63 Anonymous, "Africa Girls Going Places in the States," Daily Nation (2 July 1974), 19; Ruth Waithera (interview, Nairobi, 18 February 2011); Tecla Chembawai (interview, Eldoret, 12 January 2011).

64 Philip Ndoo, "Sang Threatens to Quit if Ouko is Not Reinstated," Daily Nation (8 April 1975), 15. 
The implications are magnified because selection for major races rests entirely on a runner having first achieved the necessary qualification standard in official competition, which for women meant races held in Kenya. Throughout the seventies and eighties, the organization of domestic track meets relied on private sponsors such as Brooke Bond, British American Tobacco (BAT), and Coca-Cola. Aspiring athletes, both male and female, depended on these meets to develop and improve their racing abilities and to record qualifying times. Recognizing this, athletes who travelled to major domestic events were to have their expenses covered by the meet's sponsor and the Kenya Amateur Athletics Association (KAAA) with varying levels of reimbursement. One report from 1978 asked athletes to compete at a meet held in Nyeri's Ruringu Stadium. They were to be given free accommodation at the Wambugu Farmers Training Centre and provided that they took the cheapest public transportation, they were to be refunded their transportation money. ${ }^{65}$ Later that year, all "promising athletes" in Kenya who took part in the All-Africa and Commonwealth Games trials held in Mombasa were to have travel costs subsidized and free accommodation provided at the Kanamai Sports Centre. ${ }^{66}$

Yet promises of support were not always met and preparations frequently did not proceed as planned. At a meet in Bungoma in 1978, the athletes complained of "little food and lack of accommodation." The situation was such that some athletes chose to sleep in the recently purchased KAAA bus. In an impressive display of resilience, after getting only four hours of sleep in the bus, John Kirimiti, Richard Juma, and Christopher Kipkurgat ran some of the best marathon races at that time in Kenya. Kirimiti won in 2:18, then the fourth fastest time ever by a Kenyan, with Juma second in 2:22, and Kipkurgat third in 2:23. ${ }^{67}$

The KAAA also often did little in terms of holding competitions though this was one of its basic functions. This was of utmost importance because as one official document noted:

Kenya Amateur Athletic Association organised competitions sometimes are the only challenge for the many talented young Kenyan runners who cannot make their way overseas. However, a financial problem for the Athletic Association is the registration of the many talents. Unfortunately, these young talents can't be offered a specific competition programme to a sufficient extent. ${ }^{68}$

65 Nation Sports Reporter, "All Set for Nyeri Meeting," Daily Nation (15 March 1978), 30.

66 Ochieng' Angela, "Room for All in Pre-Games Trials," Daily Nation (14 June 1978), 30.

67 Nation Sports Reporter, "Two Records Fall as 10 Qualify for Club Games," Daily Nation (10 April 1978), 18.

68 Walter Abmayr, Track E Field Best Performances: Kenya 1982 (Nairobi: Abmayr, 1983), 3. 
British coach, sport journalist and international runner Bruce Tulloh, based in Kenya at the time, was more critical, stating: "To speak bluntly, Kenya [AAA] has derived an immense amount of prestige in the world from the performances of a handful of runners, but has done nothing for the sport in return." ${ }^{69}$ Tulloh cited one seven-month stretch of time from the pre-African Games selection meet in early December 1972 to the Brooke Bond-sponsored meet on 26 May 1973 in which not a single track meet took place, despite salaried KAAA executive officers and Sports Officers stationed in every province. This was a very different scenario to the athletic facilities and race opportunities that could be accessed abroad. Without regular opportunities to race, aspiring athletes could not gain the race experience necessary to obtain international-level qualifying times, nor the feel of competition.

The Sunday Nation discussed the importance of improving the caliber of domestic competitions, advancing the notion that the "main problem... faces so many talented African athletes - lack of top-flight international competition."70 It reported that although "courage and determination have always spurred our African athletes to reach the top (...) they really have to struggle against the more experienced and established world-class runners." 71 European and American athletes were seen as having the chance to compete routinely against their "opposite numbers on other continents" while the chance for Kenyan athletes to face international competition came rarely, for women far more so than men.

Another limiting factor was the dearth of tracks with surfaces conducive to fast running. The first all-weather track was not built until 1983, and before then, all races were conducted on grass or dirt. In Iten, a stadium with a dirt track was built in 1959, opened for the first time on the occasion of a royal visit in February of that year, and remains in heavy use today. ${ }^{72}$ For athletes who remained based in Kenya, these unreliable track surfaces posed a significant challenge to recording the qualifying times necessary for racing in international meets or for garnering the attention of US college recruiters. For instance, at a meet in Kisii in October of 1973 one reporter observed, the "indifferent track and poor facilities put paid to the expectations" of athletes seeking the Commonwealth Games qualifying marks. ${ }^{73}$ Nearly all the athletes competing that day blamed the meager performances on the rain that had resulted in a heavy grass track.

69 Bruce Tulloh, "Second to None in Natural Ability...," Daily Nation (14 June 1973), 22.

${ }^{70}$ Hezekiah Wepukhulu, "Judith Ayaa: A Munich Medal?," Sunday Nation (24 August 1969), 43.

71 Hezekiah Wepukhulu, "Judith Ayaa: A Munich Medal?," Sunday Nation (24 August 1969), 43.

72 Kenyan National Archives, DC/ELG/1/7, "1959 Annual Report: ElgeyoMarakwet."

73 Joshua Okuthe, "Kisii Meeting a Disappointment," Daily Nation (8 October 1973), 22. 
To US Sports Affairs officer for Africa, Mal Whitfield, commenting after attending the Kenya Colleges and Schools Athletics Championships at Kakamega's Bukhungu Stadium: "Kenyans have a better natural ability. But they just may not have the necessary facilities to enable them to get the best out of their talent. There are some things that one may not be able to achieve if devoid of facilities." 74

The 1980 Kenyan National Championships, held at Bukhungu Stadium, offered further proof of the deleterious effect that a poor track surface could wreak on runners' times. Kenya's best athletes had converged on Kakamega in front of a capacity crowd for the Championships, yet by the end of the first day, "only two Kenyan records had fallen." As the Daily Nation described: "[T] his gives a misleading impression of the performances put up by the athletes. They did enough to deserve more." ${ }^{75}$ A heavy downpour halfway through the day, after the two records were set, had loosened the surface of the track. ${ }^{76}$ As the newspapers reported: "No athlete knew better of the cruelty of the slippery murram than those who used lane one of the track. It had soaked enough water from the grass of the field to give its user a substantial handicap against other competitors." 77

Hardships particular to Kenyan athletics, from the absence of tracks with a consistently reliable surface to long stretches of time without officially sponsored meets, adversely affected all runners who were based in the country. However, as a group, women were more negatively impacted than the men who had opportunities to enter the "pipeline" to the United States. As one reporter noted:

Nowhere will the contest be hotter than in the women's programme. Our track Cinderellas have had all too few opportunities of overseas competition - and are determined not to miss out this time in making the grade for Munich. ${ }^{78}$

To compete at the Olympics and other major competitions, women were forced to rely on domestic track events to attain the qualifying times required to enter the international scene. These local track meets were far from an optimal environment for fast times because they were contested on highly variable surfaces - if they were held at all. These barriers to achieving fast times intensified the difficulty of qualifying for international championships - a vicious cycle, particularly for women. Track scholarships

74 Johnny Pewa, "Soccer Fans Turn out to Give Athletes Morale," Daily Nation (3 August 1985), 21.

75 Roy Gachugi, “Athletes Thrill Capacity Crowd,” Daily Nation (24 May 1980), 20.

76 Both of the new records had been achieved before the rain.

77 Roy Gachugi, “Athletes Thrill Capacity Crowd,” Daily Nation (24 May 1980), 20.

78 Peter Moll, "Munich Girls," Daily Nation (11 August 1971), 37. 
for women were not fully in place until the enforcement of Title IX became widespread in the early 1980s. While women were forced to wait, Kenyan men took full advantage of the range of races and scholarship opportunities in the United States. Newspaper reports from the national press in Kenya make clear the challenges at the local and national levels that confronted those who were left behind.

\section{Conclusion}

Newspapers are a set of texts that deepen the knowledge about African athletes from a different era and continue to do so today. Sports articles provide a unique record and blend of the thoughts and feelings of the athletes, coaches, officials, journalists, and spectators. The experiences and voices of athletes, male and female, have been immortalized in the sports sections of Kenyan newspapers. This type of qualitative data, embedded within domains of popular culture, like sport, rarely appears in the official archival record. The reports also make clear the economic dimension of athletics in Kenya. Poor track facilities and limited racing opportunities affected all runners based in Kenya during this period but women had systematically fewer ways to bypass this by racing abroad.

Evidence of the effects of early pregnancy, of a lack of marital support and of inadequate facilities and unequal opportunities on women's running should be integrated into wider historical discussion of gender relations and economic constraints in Kenya. Both cultural and economic factors undoubtedly influenced why Kenyan women's running developed differently from men's. By excavating and analyzing what has been reported on sport within Kenya's major dailies, the vast archive of reports available on athletics can be brought to bear.

Influenced by the interplay of journalists and their readership but free from direct oversight and government censorship, articles in Kenya's two major dailies, Daily Nation and The East African Standard, offer a substantial repository of data for historians interested in studying sport as well as a valuable lens through which to address wider historical questions. The challenge for the historian interested in studying African women is often to elicit significant facts from documents intended for other purposes. Sports articles, too, may shed light on female athletes' experiences even when the main thrust of the reporting concerned male athletes. It is necessary to begin to discern the utility of the sport section as a source for Africanist historians of women and gender. The print media covers the changes in gender and sport within a region where athletics has been a source of tremendous local and global recognition or in the words of Bea Vidacs, "studying sports can yield important insights about non-sporting aspects of African societies."79

79 Vidacs, "Through the Prism of Sports," 337. 


\section{References}

Anderson, David, Eroding the Commons: The Political Ecology in Baringo, Kenya 18901963 (Oxford: James Currey, 2002).

Anderson, David, and Nic Cheeseman, "An Introduction to African Politics," in: David Anderson, Nic Cheeseman and Andrea Scheibler (eds.), Routledge Handbook of African Politics (Abingdon: Routledge, 2013), 1-8.

Bale, John, The Brawn Drain (Urbana: University of Illinois Press, 1991).

— John Bale, Craig Sharp, Tim Noakes and Norman Myers (eds.), East African Running: Toward a Cross-Disciplinary Perspective (London: Routledge, 2007), 11-23.

Bale, John, and Joe Sang, Kenyan Running: Movement Culture, Geography and Global Change (London: Routledge, 1996).

Barber, Karin, "Popular Arts in Africa," African Studies Review 30-3 (1987), 1-78.

__, "Preliminary Notes on Audiences in Africa," Africa 67-3 (1997), 347-362.

Berger, Iris, and Frances White (eds.), Women in Sub-Saharan Africa: Restoring Women to History (Bloomington IN: Indiana University Press, 1999).

Butler, Mark (ed.), IAAF Statistics Handbook (London: IAAF Media \& Public Relations Department, 2009).

Chepyator-Thomson, Jepkorir Rose, "African Women Run for Change: Challenges and Achievements in Sports," in: Jepkorir Rose Chepyator-Thomson (ed.), African Women and Globalization: Dawn of the $21^{\text {st }}$ Century (Trenton NJ: Africa World Press, 2005), 239-258.

Cornwall, Andrea, "Introduction: Perspectives on Gender in Africa," in: Andrea Cornwall (ed.), Readings in Gender in Africa (Oxford: James Currey, 2005), 1-19.

Coquery-Vidrovitch, Catherine, African Women: A Modern History (Boulder CO: Westview Press, 1997).

Faringer, Gunilla, Press Freedom in Africa (New York: Praeger, 1991).

Finn, Adharanand, Running with the Kenyans: Discovering the Secrets of the Fastest People on Earth (London: Ballantine Books, 2012).

Fletcher, Marc, and Lizelle Bisschoff, "African Sport in the Global Arena: Contemporary Approaches and Analyses," Critical African Studies 6-2/3 (2014), 123-133.

Frederiksen, Bodil Folke, "Gender, Ethnicity and Popular Culture in Kenya," The European Journal of Development Research 6-2 (1994), 52-62.

— Improvement, Protest and Connections," Africa 81-1 (2011), 155-172.

Gadsden, Fay, "The African Press in Kenya, 1945-1952," Journal of African History 21-4 (1980), 515-535.

Godia, George, "Sport in Kenya," in: Eric Wagner (ed.), Sport in Asia and Africa (New York: Greenwood Press, 1989), 260-281.

Hunt, Nancy, "Placing African Women's History and Locating Gender," Social History 14-3 (1989), 359-379.

Imam, Ayesha, Amina Mama and Fatou Sow (eds.), Engendering African Social Sciences (Dakar: CODESRIA, 1997).

Jones, Denise, "Women and Sport in South Africa: Shaped by History and Shaping Sporting History," in: Ilse Hartmann-Tews and Gertrud Pfister (eds.), 
Sport and Women: Social Issues in International Perspective (London: Routledge, 2003), 130-144.

Lynch, Gabrielle, I Say to You: Ethnic Politics and the Kalenjin in Kenya (Chicago: University of Chicago Press, 2011).

Mahlmann, Peter, "The Role of Sport in the Process of Modernisation: The Kenya Case," Journal of Eastern Africa Research and Development 23 (1993), 160-175.

Manners, John, "In Search of an Explanation," in: Dave Prokop (ed.), The African Running Revolution (Mountain View CA: World Publications, 1975), 26-40.

_, "African Recruiting Boom," in: Dave Prokop (ed.), The African Running Revolution (Mountain View CA: World Publications, 1975), 62-69.

—_, “Kenya's Running Tribe,” The Sport's Historian 17-2 (1997), 14-27.

, "Raiders from the Rift Valley: Cattle Raiding and Distance Running in East Africa," in: Yannis Pitsiladis, John Bale, Craig Sharp, Tim Noakes and Norman Myers (eds.), East African Running: Toward a Cross-Disciplinary Perspective (London: Routledge, 2007), 40-50.

Mayes, Randall, The Cybernetics of Kenyan Running (Durham NC: Carolina Academic Press, 2005).

Naidoo, Prishani, and Zanele Muholi, "Women's Bodies and the World of Football in South Africa," in: Ashwin Desai (ed.), The Race to Transform: Sport in PostApartheid South Africa (Cape Town: HSRC Press, 2010), 105-145.

Njororai, Wycliffe, "Colonial Legacy, Minorities and Association Football in Kenya," Soccer E Society 10-6 (2009), 866-882.

_- "Global Inequality and Athlete Labour Migration From Kenya," Leisure/ Loisir 34-4 (2010), 443-461.

Ogola, George, "Confronting and Performing Power: Memory, Popular Imagination and a 'Popular' Kenyan Newspaper Serial," African Studies 64-1 (2005), $73-85$.

—, "The Idiom of Age in a Popular Kenyan Newspaper Serial," Africa 76-4 (2006), 569-589.

, "If You Rattle a Snake, Prepare to be Bitten: Popular Culture, Politics and the Kenyan Media," in: Herman Wasserman (ed.), Popular Media, Democracy and Development in Africa (Abingdon: Routledge, 2011), 123-146.

Okigbo, Charles, Festus Eribo, Mary Kizito and Christine Kyayonka, "Beyond Cameroon: Model Content Analysis from East and West Africa," in: Festus Eribo and Enoh Tanjong (eds.), Journalism and Mass Communication in Africa: Cameroon (Lanham MD/Oxford: Lexington Books, 2002), 133-150.

Pitsiladis, Yannis, John Bale, Craig Sharp, Tim Noakes and Norman Myers (eds.), East African Running: Toward a Cross-Disciplinary Perspective (London: Routledge, 2007), 1-8.

Prokop, Dave (ed.), The African Running Revolution (Mountain View CA: World Publications, 1975).

Saveedra, Martha, "Football Feminine - Development of the African Game: Senegal, Nigeria and South Africa," Soccer Ẽ Society 4-2 (2003), 225-253.

Shehu, Jimoh (ed.), Gender, Sport and Development in Africa: Cross-Cultural Perspectives on Patterns of Representations and Margalization (Dakar: CODESRIA, 2010).

Sikes, Michelle, "Choosing to Run: A History of Gender and Athletics in Kenya," $\mathrm{PhD}$ dissertation, University of Oxford (Oxford, 2014).

Sikes, Michelle, and Grant Jarvie, "Women's Running as Freedom: Development and Choices," Sport in Society 17-4 (2012), 507-522. 
Sikes, Michelle, and John Bale (eds.), Women's Sport in Africa (Abingdon: Routledge, 2014).

Tanser, Toby, Train Hard, Win Easy: The Kenyan Way (Mountain View CA: World Publications, 1997).

— More Fire: How to Run the Kenyan Way (Pennsylvania: Westholme Publishing, 2008).

Tucker, Ross, Vincent Onywera and Jordan Santos-Concejero, "Analysis of the Kenyan Distance Running Phenomenon," International Journal of Sports Physiology Performance 10-3 (2015), 285-291.

Vidacs, Bea, "Through the Prism of Sports: Why Should Africanists Study Sports," Afrika Spectrum 41-3 (2006), 331-349.

Wirz, Jurz, Run to Win:Training Secrets of the Kenyan Runners (Oxford: Meyer \& Meyer Verlag, 2006). 